\title{
History, Originality, ANd Genesis
}

\section{Donald G. Marshall}

In the twenty-second chapter of Genesis, God orders Abraham to take his son-his only son-Isaac to a mountaintop in the land of Moriah and there offer him up as a burnt offering. This story, as brief and shattering as a hammerblow, contains the essence of biblical religion. In the reader's experience, faith and revulsion struggle irresolvably. The reader who fails to demand that God explain His appalling command in terms that satisfy our human moral sense shows not faith, but disbelief. Whoever accepts the story with cold and smug confidence, whoever refuses to plunge empathetically into the anguish of Abraham, shows that he lacks the justice and mercy God requires of every human being. Such a reader turns Abraham into a puppet and God into a monster.

Those who teach Genesis encounter not only in their students, but in themselves, the deadening effect of 3,000 years of accumulated familiarity. An orthodox reading finds Abraham's faith unflinching and God's testing a mere charade in the midst of which Abraham and the reader are already confident of the final reward. Such a reading takes the story entirely too much on faith-a false faith that prudently disarms any risk of being tested. An authentically religious reading of Scripture, on the contrary, is anything but accepting, even though what we call "critical distance" never emerges. For a believer the text is full of thorny challenges -Jacob wrestling God, Job's clear conscience in the face of punishment, Jesus's shocking conundrums: the first shall be last; I bring not peace but the sword - so that reading it is like crossing a spiritual desert toward a land whose promise is sure to the exact degree that that promise contradicts every human certainty. Those who wrestle with the text may be broken by it, but only they can win a blessing.

The strength of Harold Bloom's commentary in The Book of $J$ is the strength of his spiritual wrestling with Scripture. Since he explicitly rejects reading in the traditional mode of belief, the term "spiritual" may seem misleading. He insists that to read J, you must peel away "three stages of varnish, plastered on by the rabbis, the Christian prelates, and the 
scholars" (306). "J is not a religious writer," he contends, adding that "the distinction between sacred and secular writing is always a sociopolitical and never a literary judgment" (290). J does not write in the service of the Yahweh known to cultic worship (280-81), nor faithfully preserve and arrange traditional material (289). The religious imagination, Bloom asserts, "is always stunted by anxieties of representation" (282). By contrast, J unflinchingly presents the reader with the uncanny, restless, incommensurate "anthropomorphic" Yahweh, filled with zest, life, and capricious passions; a God whose "leading quality is not holiness, or justice, or love, or righteousness, but the sheer energy and force of becoming, of breaking into fresh being" (294); and consequently a personality unassimilable by Western theology (282). Yahweh is the core of J's book, and Bloom's central argument is that what little capacity we have to appreciate this uncanny God depends on what we have learned about literary character from the very writers, like Shakespeare and Freud, who owe their greatness to J's influence (303). Whether "religion" is as Bloom describes, I will not dispute here. But I insist that he reads the text in exactly the spirit I have argued that it demands.

Reading the story of Abraham and Isaac in this spirit requires a strangely self-divided imaginative activity. Whatever intelligence and moral insight we can bring to that story originates in the only source we have, our own experience transmuted by reflection. Yet an adequately responsive reading opens us to a heartcrushing experience that transforms us beyond anything our will or self-consciousness could bring into being. We suffer a blow that comes too late to evade, and yet our most authentic being resides precisely in our capacity to suffer that blow. This two-sided phenomenon is what Bloom means by "originality." We receive only in the measure we bestow. Bloom aptly cites Kierkegaard's remark that here you become father to yourself (306). "Originality" in this sense is not a matter of what is chronologically early. It is a constant primacy which the passage of time can never efface and for which another name is "spirit."

Bloom's reading is nothing if not spirited and takes the form of disciplined attention to the text. Under Bloom's eye, the text reveals itself as wilful, dynamic, becoming and overcoming. Its most salient feature is ellipsis, which generates strange juxtapositions, antitheses, paradoxes. False etymologies, disorienting repetitions, and a host of other wordplays 
energize the text until it escapes the coherence of plot, the consistency of character and motivation, and the focus of theme. (Friends have warned me that the translation must be used with caution - that it is not just occasionally inaccurate, but occasionally tendentious. I do not know enough to test its accuracy. But I am certain that no translation could claim to be accurate that lacks this one's energy.) The fundamental device of J's text is irony, Bloom argues, an irony founded "upon the play of incommensurates" (293). When he is reading at his shrewdest, Bloom juxtaposes incidents, fills in one character by contrasting it with others, folds the text over itself, and pierces to the passions that course along beneath these elliptical tales. Through his commentary, the text itself becomes a spirited personality, and in turn, precisely because his readings vibrate with his strongly personal voice, they call forth, provoke, a reader's desire for an equally passionate encounter with the text.

"Originality" and "personality" are the joint conceptual supports of Bloom's approach to this and, in all his books, to every text he regards as worthy of serious reading. "Originality" and "personality" are features we attribute to the text. But it is more accurate to say that they mark the peculiar experience we have in the presence of these "strong" texts, an experience whose very intensity invites projection into a region beyond the experience of reading.

Bloom personifies his experience of the exuberant, living presence of the text as "the author J." He then, notoriously, elaborates that authorial personality by speculating that "J" was a woman. I do not doubt he sincerely meant this when he wrote it, even though he admits he was motivated in part by a polemical desire. He wanted to lay waste the camp of feminists who read Genesis - and indeed all of Scripture - reductively, as the cornerstone of patriarchy. Bloom's less narrow purpose was to shake us from our dogmatic slumbers so that we read the text afresh, and in particular he wanted us to see how complex, how undeferential was the author's attitude toward the patriarchs and how impressively alive were her women characters. All that granted, succumbing to the imp of the outrageous is never prudent, even if it attracts attention to a book one very much wants to be read. His commercial and journalistic success is also his punishment, and he has publically regretted his speculation. Certainly, he presents no evidence to support it - though that lack should remind us that there is 
equally no explicit evidence that the author was a man, a supposition that seems "natural" or "self-evident" only to unexamined prejudice.

The real point, however, is that Bloom talks about $\mathrm{J}$ in a literalizing way that betrays his own insistence that she is a "biographical fiction" who came "after my interpretation of $\mathrm{J}$, and is dependent upon that interpretation, rather than determining my exegesis" (298). Though he repeatedly apologizes for them, one speculation leads to another, until we get a series of propositions that divide their allegiance between scholarly reconstruction and historical romance. J, Bloom suggests, was a woman in the court of Rehoboam, a contemporary of the male chronicler who wrote 2 Samuel. After the pinnacle of Hebrew culture was reached in the reign and figure of David, there followed the skeptical "Enlightenment" under his son Solomon and then the satisfyingly symmetrical disaster of Solomon's feeble son Rehoboam. The achievement of Davidic humanism, Bloom argues, is the unstated and critical undercurrent of the book of J, whose author even works in a few wordplays on Rehoboam's name and deeds to mock David's ineffectual descendant. This contextualization is surprising from one who rarely misses a chance to scorn "history," what he calls "the reign of mere fact" (285).

The ambiguity of Bloom's position is a symptom of the problematic relation in which the whole of modernity stands to history, as well as to tradition, understood-or misunderstood-in the wake of historicism. Historicism regards ancient religious texts as the product of collective processes over long periods. The very notion of a "Book of J" rests on the nineteenth-century scholarly labors nowadays condensed under the rubric of the "Graf-Wellhausen" or "Documentary Hypothesis." The scholars argued that Scripture was an editor's compilation of historically separate strands by various authors who held distinct, even conflicting conceptions of God and had different purposes for writing. The scholars prided themselves on the ingenuity with which they isolated each strand. One clue was provided by consistent differences in diction, especially in the name given God-one strand calls God "Yahweh" (the author labelled "J" because German scholars transliterated the Hebrew as "Jahweh"), another "Elohim" (the author "E"). But even more important was an acutely rationalist sensitivity to gaps, inconsistencies, illogicalities-anything in the text that violated a nineteenth-century German scholar's highly 
developed common sense. These irregularities were taken to be ill-patched seams in the garment of Torah, whose variegated splendor was picked apart and sorted into monochrome piles of patches. This achievement is a monument to rationalist historicism. We are given a picture of a compiler who has too much reverence for the heap of scrolls he has inherited to discard any and who lacks the authority, the daring, the originality to fuse them into an expression of his (or her!) powerful personal vision.

I do not pretend to criticize this historicist approach-given my own intellectual formation within the modern world I can scarcely imagine, let alone authentically live any other way of reading the text. And yet I find it deeply troubling. The authority Scripture possessed for a pre-critical reader generated a powerful experience that could claim to be genuinely religious. Post-critical reading transfers authority to the scholarly commentary which turns Scripture into an object of investigation, so that the pre-critical reading shrivels into the merely uncritical, a mindless fundamentalism. Even more, pre-critical "tradition" puts the current generation in the living presence of the text. Post-critical "tradition" regards what comes down to us as a few archaic survivals from a past that is dead and gone. Our only hope for authenticity then becomes the quest for the "original," which we can reach only by self-destructively breaking the very threads of tradition which are our only genuine contact with it. Caught in this dilemma, Bloom cannot help seeing the text and the whole tradition that flows out of it as a massive and by no means unconscious conspiracy to neutralize, distort, and repress the originating power of "J," envisioned as a mighty individual who stands apart from the feeble mass mind of every community. It is certainly strange to have the Documentary Hypothesis reified in this way and then respiritualized as historical romance. But of course historical scholarship and historical romance are twin births of the nineteenth century.

I have neither Wellhausen's scholarship nor Bloom's imagination. But I think I owe to the philosopher Hans-Georg Gadamer a different understanding of tradition. Tradition is not a specious continuity used to repress the reality of discontinuity but is, precisely, the recurring dialectic of continuity and discontinuity, of certainty and its contradiction, which marks all our experience.

So to return to the story of Abraham and Isaac, apart from any religious 
tradition, whatever spiritual power it is able to bestow on me flows out of the traditions of philosophical reflection and scholarship. I am thinking, for instance, of Immanuel Kant's indignant criticism of Abraham's obedience on the ground that Abraham could not know with certainty that it was God who levied this command, but he could never doubt the truth of the moral law that he must not kill his son. Not many years later, in Fear and Trembling, Soren Kierkegaard's pseudonymous author Johannes Climacus can bring to no resolution his meditation on Abraham and Isaac. By no means does he reject Kant's rationalist morality, but instead embraces it uncompromisingly as precisely the stage one must pass through to reach the infinite resignation of the Knight of Faith. Far from numbing or soothing a reader, these thinkers and scholars, in Gadamer's pregnant phrase, make the text speak again, so that it grips the reader as unshakably as the Ancient Mariner. Perhaps contrary to his own intent or selfunderstanding, I would enroll Bloom in this tradition. 